\title{
Thoughts on Customer Relation Management of Small and Medium Commercial Banks
}

\author{
Kui Yu \\ School of Economics and Management, Yibin University, Yibin,644000, China
}

\begin{abstract}
Keywords: customer relation management; small and medium commercial bank; business operation
\end{abstract}

\begin{abstract}
With comprehensive interest rate liberalization in China in 2014, market competitions of banking industry become increasingly fierce. The survival pressure of small and medium commercial banks becomes heavier and heavier. Customers have become strategic resources of small and medium commercial banks. Enhancement of customer relation management becomes the most important business strategy of small and medium commercial banks. This paper introduces the concept and connotation of customer relation management, analyzes current situations and problems of implementation of customer relation management by small and medium commercial banks and finally puts forward solutions.
\end{abstract}

\section{I.Overview of customer relation management}

(I) Implication of customer relation management

Different scholars have different explanations for customer relation management. Some think it is an advanced information technology. Some consider it is an operation principle and management mode. What is customer relation management? What's its essence? In my opinion, customer relation management means enterprises influence customers' behaviors and choices through a series of measures and behaviors so as to add the number of customers, improve customer loyalty and customer satisfaction and finally make profits. In a general sense, it includes thee aspects. Firstly, enterprises establish customer-centered idea; secondly, enterprises carry out relation creation for customers so as to establish high-quality, efficient and stable real customer relations; finally, enterprises achieve integration, i.e. unification of ideas, management and software and integration of front-desk operation and backstage service.

(II) Customer relation management of small and medium commercial banks

Since 1990s, modern western commercial banks have experienced the change from being product-centered to being customer-centered. This change is reflected in various aspects of bank management. As Chinese economy and financial system reform speed up, great and profound changes happen to external operating environment of China's commercial banks. Horizontal competitions become fierce increasingly. Whether can small and medium commercial banks further promote marketing service level, enhance exaction of potential needs of high-quality customers, permeation and expansion of high-quality customers added and increase marketing management force for high-quality customer? This is the key to deciding the success of small and medium commercial banks in new round of market competitions.

Customer relation management of commercial banks is the product of creative application of the ideal theory and method of customer relation management in commercial banks. As a new management mode, it reflects an advanced development strategy and operation idea of commercial banks. Besides, such strategy and operation idea run through management practice of commercial banks. The direction representation is software and hardware system integration with modern information technology, including business operation, customer information and data analysis. It is a uniform technical platform and intelligent service system of banking operation activities under high datamation, informatization, electronization and automation conditions. 


\section{Necessity of Customer relation management of small and medium commercial banks}

\section{(I) Need of competition environment}

Small and medium commercial banks are in the competition crack of foreign banks and Chinese large banks. Thus, the living environment is bad and the competitions are fierce. Besides, they have no advantage in the scale and capital. So, they cannot contend against foreign banks and Chinese large banks. How to better serve customers, retain new customers ad develop new customers become the key for small and medium commercial banks to gain competitive edge.

(II) Need of business mode transformation

Currently, our economy is entering information and knowledge economy era, living style of ordinary resident also changes with the era. Consumers not just want to gain fast and convenient services, but also hope to gain high-quality personalized services. If small and medium commercial banks do not change original business mode, they cannot satisfy new customer requirement. So, it is imperative to transform original business mode.

(III) Need of small and medium commercial banks to construct core competitiveness

Core competitiveness of commercial banks is not reflected in hardware facilities of business points, but reflected in humanized services. Customer relation management provides banks with a system to collect, analyze and utilize various ways to gain customer information and contributes to small and medium commercial banks to gain competitive edge in cruel competitions.

(IV) Need for better product positioning and product positioning

Through customer relation management, banks can rapidly know and predict customer demand so that banks can adapt such demand change in product positioning and marketing decision so as to reach the purpose of guiding customer consumption, attracting customers and continuously consolidating dominant position of banks in market competitions.

(V) Need for improving customer service quality and boosting customer satisfaction

Customer relation management is beneficial for identifying differences of customer value and needs so as to realize service differentiation in mechanism, means, efficiency, price and product, satisfy customers' individual needs, increase banks' benefit and boost service quality level and customer satisfaction.

\section{Problems of small and medium commercial banks in customer relation management}

1. The idea of customer relation management is unbalanced;

2. Customers' essential data and information are incomplete;

3. Customer data and information sharing are not strong;

4. Customer information analysis is not in place;

5. Customer kind classification is not detailed;

6. Customer demand mastery and guidance are not accurate;

7. The awareness and ability to help customers improve value are insufficient;

8. The operation of customer manager system is not in the optimal state;

9. Customer relation management system operation is not in the optimal state;

10. Information technology application is not in place;

11. Service innovation and management innovation are insufficient;

12. There is lack of professional personnel in information technology application;

13. Organizational structure does not adapt requirements of customer relation management mode.

\section{Reference of customer relation management strategy of foreign banks}

HSBC Group is one of the largest banking financial service institutions in the world. Its unique characteristic is to "meet your banking business need from local place and the world". Most important customers of HSBC are served by special customer relation management team set up by 
HSBC. Its customer relation management methods are very advanced so that it stands out in numerous industrial competitors. So, small and medium commercial banks can learn their practice, adopt its good points and avoid its shortcomings and improve their customer relation management level.

(I) Measures of HSBC's customer relation management

1. HSBC provides customers with one-stop financial services and products from investment, pledge, financing plan, insurance, bank card to loan etc.

2. HSBC sets up phone and e-banking business so that customers can conveniently use their own account, phone and internet for transactions anytime and anywhere.

3. HSBC differentiates different types of customers and provides individual and customized service schemes.

4. HSBC provides customers with convenient, fast, flexible and diverse services through online bank, phone bank, self-service bank, mobile bank and branches.

(II) Reference for small and medium commercial banks

1. It is necessary to enhance "customer-centered" ideological transformation of all employees in small and medium commercial banks. Customer relation management must be based on its idea.

2. Provide all-round services from all perspectives and levels through analysis of customer demand.

3. Classify customers, provide different service schemes, rationally allocate enterprise resources and boost profitability.

4. Maximize customers' lifelong value. Analyze customers' future behaviors through corresponding prediction models, continuously adjust strategies, win high customer loyalty and maximize customers' lifelong value.

\section{Analysis of customer relation management strategy of small and medium commercial banks}

Aiming at the problems of small and medium commercial banks in customer relation management and the thoughts of banks which have implemented customer management, I consider small and medium commercial banks can improve customer relation management level from the following aspects:

(I) To establish customer-oriented idea

Customer-oriented management idea is reflected in the following five aspects in small and medium commercial banks:

1. Customer-oriented idea. Small and medium commercial banks must place customer demand and benefit in the first position, mobilize all resources to make customers feel satisfied and regard customer satisfaction as the standard to evaluate work quality and work performance.

2. Marketing integration idea. Small and medium commercial banks should regard financial product marketing as a specialized cause and integrate various marketing resources to meet marketing campaign elements and realize marketing professionalization.

3. Idea of overall development of core customers. For high-quality and core customers of small and medium commercial banks, commercial banks must pay high attention to them, carry out different services and satisfy financial demand of core customers to the largest extent.

4. Individual product and service idea. Small and medium commercial banks should provide customized financial services according to customer demand, provide customer service schemes through survey and evaluation of customers and implement combinational design of financial products and various external resources available to provide professional services for customers.

5. Financial service innovation idea. Small and medium commercial banks should be very sensitive to customer demand and changes, timely refine and summarize their changes, conduct product innovation design according to feedbacks and provide customers with the latest financial products at the fastest speed.

(II) To reform enterprises organizational structure

In order to carry out customer relation management, small and medium commercial banks need 
to greatly reform management system and organizational structure, gradually adjust product-based organizational structure and business layout to customer-oriented net-shaped matrix organization and operation architecture with customer, industry, region and product as the clues, throw off original one-sided business mode with the purpose of product sales, improve bureaucratic organizational structure, boost service efficiency and realize flat management.

1. Reform original organizational structure based on functionality, classify customers and arrange different customer manages or customer manager service groups to take charge of marketing.

2. Set up different product departments in accordance with product varieties, peculiarities and types, further subdivide product structure and equip professional product managers to take charge of product management, sales, promotion and development and coordinate with customer managers to carry out marketing.

3. Set up business management service department, optimize business services, further divide functions and power, take customer service as the center and make sure customer relation management system is implemented and operated effectively.

(III) To construct reasonable business process

Business process reengineering should start from customer information acquisition until customer information is transformed to customer relation and forms interactions between enterprises and customers. Small and medium commercial banks must analyze original business process, optimize and integrate business process. During business process integration, small and medium commercial banks should design different process according to different customer groups and different occasions, fully combine features of customer groups and changes of occasions to conduct process innovation. Customer service process does not work independently. Its backstage support process is also important. So, during designing processes in allusion to different customers and different occasions, the backstage support process should be changed correspondingly. In particular, backstage support plays an important role in the aspects of efficiency, cost and risks.

(IV) To implement differential marketing strategy

Small and medium commercial banks should utilize information system to record customer information in detail, continuously collect, sort, analyze customer information, excavate customers' potential demand, subdivide customer groups, know special demands of different customers in different target markets, implement differential marketing, master customers' potential demand, formulate a package of service schemes, customize characteristic financial product combination and improve customer value and customer loyalty.

(V) To build professional customer manager team

Professional customer managers here are not the personnel with banking business knowledge, but comprehensive financial customer managers. They not only own banking business knowledge in one aspect, but also own much knowledge of non-banking business. The knowledge is not just for selling products, but also for enhancing management team strength and better understanding customer demand and meeting customer demand.

Firstly, small and medium commercial banks should stick to the principle of employing capable personnel and invest more to recruit high-quality personnel. Secondly, small and medium commercial banks should establish perfect training system, pay attention to training systematicness, comprehensiveness and continuity. Finally, during performance appraisal, small and medium commercial banks should emphasize customer-centered index and cannot regard sales performance as the only index. Comprehensive appraisal is needed to ensure stability of professional customer manager team members.

(VI) To make the best of modern information technology

1. To establish perfect information network system

Database building and implementation of online bank and multifunctional phone bank need to the support of perfect network, convenient and fast information platform. So, banks need to set up perfect information network system.

2. To utilize big data technology 
Human society has entered "big data” era. Banks' customer data, transaction data, management data and backstage information system service data present explosive growth. Small and medium commercial banks should make the best of big data technology to dig valuable information and law from mass customer data, predict customer demand and preference and establish appropriate models so as to maximize customer value, prevent customer loss, provide targeted products and services for customers and create core competitiveness which cannot be copied.

3. To take full advantage of cloud computing technology

Cloud computing greatly reduces knowledge barrier of enterprises inputting high-tech technology in customer relation management, obviously lowers rigid cost and avoids transformation risks caused by increasing marginal cost.

4. To utilize mobile business technologies

Small and medium commercial banks can use mobile business technology in each stage of customer lifecycle. These mobile business technologies can help enterprise establish customers' features, provide targeted services and respond to changes of customer status timely and effectively.

\section{References}

[1] Hu Chunlei, Study on customer relation management theory of China's commercial banks and information technology application [D]. Beijing: Capital University of Economics and Business, 2006

[2] Tong Zhizhen, Analysis and design of customer management system of small and medoum commercial banks [D]. Xiamen: Xiamen University, 2012

[3] Chen Huimin, Application of cloud computing mode in customer relation management system [J]. Modern Business Trade Industry, 2013 (8)

[4] Cui Jiushan, Study on application of service marketing in state-owned commercial banks [D]. Beijing: Capital University of Economics and Business, 2011

[5] An Jiahui, Research of customer relation management scheme of China Minsheng Banking Corp [D]. Harbin: Harbin University of Science and Technology, 2007 